\title{
Starvation of Flavobacterium psychrophilum in broth, stream water and distilled water
}

\author{
Ioannis N. Vatsos, Kim D. Thompson*, Alexandra Adams
}

Institute of Aquaculture, Stirling University, Stirling FK9 4LA, UK

\begin{abstract}
Physical changes in Flavobacterium psychrophilum, the causative agent of rainbow trout fry syndrome (RTFS), were examined over a $19 \mathrm{wk}$ period of starvation. Bacteria were maintained in either Cytophaga broth, filtered stream water, or filtered distilled water, or were maintained in broth after disinfection as a negative control for dead bacteria. Culturability and viability of the bacterium were assessed using colony-forming units (CFUs) and a commercially available live/dead kit. Antigenic profiles and general morphology of the bacterium were also examined using Western blot analysis and electron microscopy, respectively. The bacterium appeared to stop multiplying and became smaller and rounded when maintained in stream water. Its culturability declined until it was no longer possible to obtain colonies on agar plates at the end of the trial at $19 \mathrm{wk}$, and results from the live/dead kit did not correspond with the viability obtained as CFUs in culture. However, it was still possible to obtain growth of the bacterium after 36 wk with a resuscitation step in Cytophaga broth. Bacteria maintained in distilled water or treated with a disinfectant appeared non-viable using the live/dead kit and were unable to grow on agar $1 \mathrm{~h}$ after setting up the experiment; no morphological changes were observed in the bacteria maintained under these conditions. Bacteria maintained in broth were present as long, slim rods, some of which developed into 'ring' formations. Small differences were observed in the antigen profiles of the bacteria maintained under the different treatments, possibly due to a reduction in the size and metabolism of the bacteria. There was also a marked decline in the sensitivity of the PCR with bacteria maintained under the different treatments 14 wk from the onset of the study.
\end{abstract}

KEY WORDS: Flavobacterium psychrophilum • Rainbow trout fry syndrome $\cdot$ Starvation · Viability · Detection Resale or republication not permitted without written consent of the publisher

\section{INTRODUCTION}

Flavobacterium psycrophilum is the causative agent of rainbow trout fry syndrome (RTFS; Bernardet et al. 1989). It has also been associated with outbreaks of bacterial cold-water disease (BCWD) in salmonid fishes (Borg 1960). So far, little is known of the epidemiology of the disease or the survival of the bacterium outside its host. There is also little known about the portal of entry of the organism or its spread within the body of a fish (Kumagai et al. 2000, Madetoja et al. 2000, Kondo et al. 2002), although a number of infectivity trials have been conducted by different investigators, each achieving differing results (Holt 1987, Lorenzen et al. 1991, Iida \& Mizokami 1996, Madsen \&
Dalsgaard 1999, Decostere et al. 2000). For example, Lorenzen et al. (1991) demonstrated that the disease could be transmitted by cohabitation as well as by intraperitoneal injection of isolated bacteria. Whilst Iida \& Mizokami (1996) failed to transmit the pathogen by immersion, Holt (1987) found that the virulence mechanisms of the pathogen were better expressed following inoculation of muscle tissue of the host rather than the peritoneal cavity. It has been suggested that amphibians, insects or other animals may act as a reservoir for the bacterium (Brown et al. 1997). Wild fishes, or fishes escaping from farms, may also contribute to the spread of the disease, as observed by Wiklund et al. (1994). In addition, the possibility of the disease being transferred by bacteria suspended in the 
water column or in sediment also cannot be excluded. However, for this latter mode of transmission, F. psychrophilum must be able to survive outside the fish for an extended period of time.

Flavobacterium psychrophilum is considered a very fastidious organism, and problems with the culture of the bacterium have been reported (Daskalov et al. 1999, Michel et al. 1999). Under adverse conditions, it is possible that the bacterium enters a viable but nonculturable state, as in the case of many other bacterial species, such as Salmonella sp. (Dupray et al. 1997) and Yersinia ruckeri (Thorsen et al. 1992). This characteristic results in an inability to detect the pathogen in environmental samples when culture is used as the only means of identification.

The ability of Flavobacterium psychrophilum to survive under conditions of starvation was examined in this study, and changes in the organism as an adaptation to its environment are described. F. psychrophilum cells were maintained under different environmental conditions: in broth, stream water, and distilled water. Changes in the general morphology of the cells and their culturability and viability under the different conditions were examined. The sensitivity of a polymerase chain reaction (PCR) was also evaluated with respect to its ability to detect possible DNA degradation within the starved cells.

\section{MATERIALS AND METHODS}

Bacterial preparation. We used Flavobacterium psycrophilum Strain B97026, isolated from an outbreak of RTFS in the UK in 1997 and held in the bacterial collection at the Institute of Aquaculture, Stirling. A 3 d old culture, grown in modified Cytophaga broth (Anacker \& Ordal 1959) at $14^{\circ} \mathrm{C}$, was used as the stock culture from which a series of 4 treatments was prepared. Before preparing the treatments, the bacterial concentration of the stock culture was determined (total number of bacteria per $\mathrm{ml}$ ) by an acridine orange direct-counting method (AODCM) described by Hobbie et al. (1977).

The concentration of the stock culture was approximately $2.8 \times 10^{8}$ cells $\mathrm{ml}^{-1}$, as determined by AODCM, which corresponded to a colony-forming unit (CFU) count of approximately $2.8 \times 10^{8} \mathrm{CFU}$ $\mathrm{ml}^{-1}$. All bacteria stained 'green' with the live/dead kit, the use of which is described below, indicating that all were alive. The 4 treatments involved placing stock bacteria in (1) Cytophaga broth, (2) stream water, (3) distilled water, or (4) killing bacteria with Limox (400 ppm $\mathrm{H}_{2} \mathrm{O}_{2}$ and peroxyacetic acid; DiverseyLever), a disinfectant used for farm equipment; the latter bacteria were used as a negative control to represent dead bacteria. The source of the stream water was the loch at the University, which was comprised of hard, mesotrophic water, rich in anions and cations.

An aliquot of $3.5 \mathrm{ml}$ of the stock culture, equivalent to $10^{9}$ bacteria, was placed into eight $30 \mathrm{ml}$ polystyrene tubes. These were centrifuged at $3000 \times g$ for $15 \mathrm{~min}$ and the supernatants discarded; $5 \mathrm{ml}$ of distilled water filtered through a $0.2 \mu \mathrm{m}$ filter were added to 6 of the tubes, while $5 \mathrm{ml}$ Limox, diluted to obtain 400 ppm, were added to the remaining 2 tubes. The tubes were left for $10 \mathrm{~min}$ at $20^{\circ} \mathrm{C}$ before centrifuging as described above, and the supernatants were then discarded. We added $5 \mathrm{ml}$ of Cytophaga broth to 2 tubes, $5 \mathrm{ml}$ of filtersterilised distilled water to another 2 of the tubes, $5 \mathrm{ml}$ of filter-sterilised stream water to another 2 tubes, and $5 \mathrm{ml}$ of Cytophaga broth to the 2 tubes containing the bacteria treated with the disinfectant.

After preparing the bacteria in the different treatments, the total number of bacteria in each tube was determined using the AODCM. Approximately half of the bacteria were lost during the 2 centrifugations, with yields of bacteria ranging between 4.4 and $4.7 \times$ $10^{8}$ bacteria per tube. The concentration of the bacteria was finally adjusted to $4.5 \times 10^{7}$ bacterial cells ml $\mathrm{ml}^{-1}$ for each tube by adding Cytophaga broth, stream water or distilled water as appropriate. The bacterial preparations were maintained in the dark at $14^{\circ} \mathrm{C}$ for the duration of the experimental period of $19 \mathrm{wk}$.

The number of culturable cells within the 4 experimental cultures was determined on a weekly basis for the duration of the experiment. To sample the bacteria, tubes were thoroughly mixed before removing three $10 \mu$ aliquots of bacteria. These were expressed as CFUs $\mathrm{ml}^{-1}$ for samples cultured on Cytophaga agar plates. Plates were prepared in triplicate for each count and bacterial colonies were counted 3 to $4 \mathrm{~d}$ after inoculating the plates. In addition to the CFU counts, culturability was also tested by adding a $100 \mu \mathrm{l}$ aliquot of each bacterial suspension to fresh Cytophaga broth. This was tested $1 \mathrm{~h}$ after setting up the experiment and again after $9 \mathrm{mo}$, although the trial itself was concluded after $19 \mathrm{wk}$.

Live/dead kit. As well as determining the number of viable cells by culture, the number of viable cells within the stock culture and each treatment was determined using a live/dead kit. The molecular probes LIVE-DEAD BacLight viability kit used in this study differentially stains live cells versus dead cells using 2 nucleic acid stains (SYTO9-live green, propidium iodide-dead red). Stain SYTO9 readily enters both intact and damaged membranes, whereas propidium iodide only penetrates cells with damaged membranes, allowing live and dead bacteria to be differentiated. A $100 \mu$ l aliquot of each bacterial suspension, prepared in triplicate, was added to $400 \mu \mathrm{l}$ of filtered 
$0.02 \mathrm{M}$ phosphate-buffered saline (PBS, $\mathrm{pH} 7.2$ ), and $1.5 \mu \mathrm{l}$ of a $1: 1$ mixture of the 2 components of the kit was added to each bacterial suspension. After preliminary analysis with the kit, propidium iodide was substituted with ethidium homodimer-1.

The bacterial suspensions were mixed thoroughly and incubated in the dark for $10 \mathrm{~min}$. From the replicates of each treatment, 3 drops $(5 \mu l)$ were placed onto a coverslip, the corners of which had been covered with wax. A slide was then placed on top of the coverslip. The slides were inverted and examined microscopically using a Leitz Orthoplan fluorescence microscope fitted with a $200 \mathrm{~W}$ ultra high-pressure mercury lamp, and the following filters: diffusing disc $\mathrm{N}$, exciting filters BG38 and BG12, and suppression filter K430.

Bacterial suspensions were examined weekly with the live/dead kit. The first set of samples was examined $1 \mathrm{~h}$ after setting up the experiment and the last set was examined $10 \mathrm{wk}$ later.

Processing of samples for scanning electron microscopy. The first samples for scanning and transmission electron microscopy were taken approximately 4 wk after setting up the experiment and the final samples after $14 \mathrm{wk}$. In addition, a sample from the stock culture ( $3 \mathrm{~d}$ old bacteria) was also collected when the experiment was first set up. The samples were fixed with $2.5 \%(\mathrm{v} / \mathrm{v})$ glutaraldehyde for $2 \mathrm{~h}$, then passed through a $0.2 \mu \mathrm{m}$ polycarbonate filter membrane (Millipore) to collect bacterial cells on the membrane. The membranes were placed in small plastic Petri dishes, to which was added $0.1 \mathrm{M}$ sodium cacodylate buffer to cover the membranes. The membranes were incubated overnight at $4^{\circ} \mathrm{C}$, before postfixing in $1 \%$ osmium tetroxide in sodium cacodylate buffer for $2 \mathrm{~h}$. After dehydration through an ethanol series $30 \%$ for $30 \mathrm{~min}, 60 \%$ for $30 \mathrm{~min}, 90 \%$ for $30 \mathrm{~min}, 100 \%$ for $30 \mathrm{~min}$ and $100 \%$ for $1 \mathrm{~h}$ ), a mixture of $100 \%$ ethanol:hexamethyldisilazane (HMDS) was added to the membranes at a ratio of 1:1 for $30 \mathrm{~min}$. We made 2 changes of HDMS at 30 min intervals, and the membrane filters were then left to air-dry overnight. Small pieces of the filter membranes, approximately $0.5 \mathrm{~cm}$ in size, were cut, mounted on stubs, and sputter-coated. They were viewed with a Philips 500 SEM at $12 \mathrm{kV}$ (Nation 1983).

Processing of samples for transmission electron microscopy. Bacterial samples were fixed in $2.5 \%(\mathrm{v} / \mathrm{v})$ glutaraldehyde for $2 \mathrm{~h}$ as described above. We added $1 \mathrm{ml}$ of each bacterial suspension to an equal volume of $5 \%(\mathrm{v} / \mathrm{v})$ glutaraldehyde in $0.1 \mathrm{M}$ sodium cacodylate buffer to give a final concentration of gluteraldehyde at $2.5 \% \mathrm{v} / \mathrm{v}$. The samples were centrifuged at $3000 \times g$ for $15 \mathrm{~min}$, and the supernatants were discarded taking care not to disturb the pellet, before adding $500 \mu \mathrm{l}$ of $0.1 \mathrm{M}$ sodium cacodylate buffer to each tube. The samples were incubated overnight at $4^{\circ} \mathrm{C}$. The buffer was carefully removed to prevent disturbing the pellet, and $50 \mu \mathrm{l}$ of $2 \%(\mathrm{w} / \mathrm{v})$ agar prepared in filter-sterilised distilled water at a temperature of $45^{\circ} \mathrm{C}$, were added to the pellet. The agar was thoroughly mixed with the pellet by pipetting up and down several times and was then allowed to cool. The agar plugs were removed from the tubes and cut into 6 to 8 smaller pieces. The small pieces were post-fixed in $1 \%$ osmium tetroxide in sodium cacodylate buffer. The osmium was removed and $2 \%$ uranyl acetate in $30 \%$ acetone was added for $1 \mathrm{~h}$ in the dark. After dehydration through an acetone series at $20^{\circ} \mathrm{C}(60 \%$ for $40 \mathrm{~min}, 90 \%$ for $40 \mathrm{~min}, 100 \%$ for $40 \mathrm{~min}$ and $100 \%$ acetone for $1 \mathrm{~h}$ ), the samples were infiltrated with Spurr's resin using a rotator mixer. A mixture of 1:1 acetone:Spurr's was added overnight, followed by further infiltration with $100 \%$ Spurr's resin for $24 \mathrm{~h}$. Finally, the small pieces were embedded in green block-moulds and left to polymerise at $60^{\circ} \mathrm{C}$ for $48 \mathrm{~h}$. Sections $100 \mathrm{~nm}$ in thickness were prepared, and these were stained for 2 min with uranyl acetate saturated in $50 \%$ ethanol before placing the sections in lead citrate for $7 \mathrm{~min}$. They were viewed with a Philips TEM 301 electron microscope at $80 \mathrm{kV}$.

Sodium dodecyl sulphate polyacramide gel electrophoresis (SDS-PAGE). An aliquot of each bacterial suspension was sampled $8 \mathrm{wk}$ after setting up the experiment, each aliquot containing $6.8 \times 10^{8}$ bacterial cells. These were placed in $1.5 \mathrm{ml}$ microcentrifuge tubes, and centrifuged for $15 \mathrm{~min}$ at $3000 \times \mathrm{g}$. Bacterial pellets were resuspended in $100 \mu \mathrm{l}$ of deionised water and $25 \mu \mathrm{l}$ of sample buffer ( $5 \times$ strength) was added to each of the samples, which were then boiled for 10 min. Finally, the samples were centrifuged at $13000 \times g$ for 5 min prior to analysis of the supernatants. An aliquot of the stock culture containing the same number of the bacteria as the experimental samples, collected after the setting up of the experiment, was also processed and used as a comparison.

A $12 \%$ polyacrylamide gel was prepared according to the method of Laemmli (1970). A preparation of broad-range molecular weight markers (BioRad) were added to the first well $(10 \mu \mathrm{l})$ and $15 \mu \mathrm{l}$ of each sample were added to the remaining wells. The gel was run at $70 \mathrm{~V}$ for approximately $3 \mathrm{~h}$ at $4^{\circ} \mathrm{C}$. It was then stained using a silver-staining kit (Sigma).

Western blot analysis. Bacterial components separated by SDS-PAGE as described above were transferred onto nitrocellulose membranes as described by Wiens et al. (1990) by applying $60 \mathrm{~V}$ for $70 \mathrm{~min}$. The nitrocellulose membranes were then incubated overnight at $4^{\circ} \mathrm{C}$ in $1 \%(\mathrm{w} / \mathrm{v})$ bovine serum albumin (BSA) in Tris buffered saline (TBS). After washing 3 times with TBST (TBS with $0.1 \%$ [v/v] Tween 20) for 10 min at each wash, the membranes were incubated 
for $2 \mathrm{~h}$ at $20^{\circ} \mathrm{C}$ with a $1 / 1000$ dilution of rabbit antiFlavobacterium psychrophilum serum raised against Strain B97026 (Faruk et al. 2002). The membranes were washed 3 times as previously described and incubated for $1 \mathrm{~h}$ at $20^{\circ} \mathrm{C}$ with a $1 / 100$ dilution of biotinlabelled anti-rabbit immunoglobin, IgG (Diagnostics Scotland). The membranes were again washed and then incubated for $1 \mathrm{~h}$ at $20^{\circ} \mathrm{C}$ with a $1 / 100$ dilution of streptavidin labelled with peroxidase (Diagnostics Scotland). After washing 3 times with TBST, once with TBS and once with PBS, bands were visualised by adding chromogen and substrate $(2 \mathrm{ml}$ of $0.3 \%$ [w/v] 4 chloro-napthol in methanol, $10 \mathrm{ml} \mathrm{PBS}$ and $10 \mu \mathrm{l} \mathrm{H}_{2} \mathrm{O}_{2}$ ). The reaction was finally stopped by soaking the membranes in distilled water for $10 \mathrm{~min}$.

PCR analysis. After $14 \mathrm{wk}$ from the onset of the study, approximately $2 \times 10^{7}$ bacteria were removed from each treatment and placed in $1.5 \mathrm{ml}$ sterile tubes, which were then centrifuged at $3000 \times g$ for $15 \mathrm{~min}$. Extraction of DNA from bacterial pellets was performed using a DNA extraction kit (BACC2, Nucleon) with the omission of RNase treatment. After extraction, the DNA pellets were re-suspended in $100 \mu \mathrm{l}$ of sterile nano-pure water.

A nested PCR was used for the amplification of Flavobacterium psychrophilum DNA, using primers described by Toyama et al. (1994). Ready-to-go PCR beads (Amersham Pharmacia Biotech) were used for the reaction, and this was performed according to the parameters described by Izumi \& Wakabayashi (1997): preheating cycle at $94^{\circ} \mathrm{C}$ followed by 35 amplification cycles of $94^{\circ} \mathrm{C}$ for $30 \mathrm{~s}, 51^{\circ} \mathrm{C}$ for $90 \mathrm{~s}$ and $72^{\circ} \mathrm{C}$ for $120 \mathrm{~s}$, and a final cycle of $72^{\circ} \mathrm{C}$ for $5 \mathrm{~min}$.

The sensitivity of the PCR was determined for both the single-round PCR and the nested PCR, using a range of dilutions $\left(10^{8}\right.$ to $10^{4}$ cells $\left.\mathrm{ml}^{-1}\right)$ prepared from the Flavobacterium psychrophilum stock culture.

Statistics. Statistical analysis was performed on data obtained from the live/dead kit to compare the viability between the broth and stream-water treatments. A 1-way analysis of variance (ANOVA) was carried out after performing an Anderson-Darling test for normality. Tukey's HSD-test identified the significantly different groups where $\mathrm{p}<0.01$ was considered significant.

\section{RESULTS}

\section{Total number of bacteria and number viable in each treatment}

The bacteria present in the stock culture used to set up the experiment appeared culturable on agar plates and viable with the live/dead kit when tested at the start of the experiment.
The first sampling of the bacteria maintained under the different experimental conditions was made $1 \mathrm{~h}$ after setting up the treatments. When bacteria from the different treatments were placed into fresh Cytophaga broth, growth was only obtained with bacteria sampled from the tubes containing bacteria in broth or stream water. Approximately $90 \%$ of the bacteria $\left(4 \times 10^{7} \mathrm{CFUs} \mathrm{ml}^{-1}\right)$ maintained in broth were culturable on agar, while approximately $40 \%$ of the bacteria $\left(8 \times 10^{7} \mathrm{CFUs} \mathrm{ml}^{-1}\right)$ maintained in the stream water were culturable (Table 1). All bacteria appeared viable with the kit at this time. No bacterial growth was obtained from cultures in tubes containing either bacteria placed in distilled water or bacteria treated with the disinfectant. All bacteria in these 2 treatments also appeared non-viable with the live/dead kit.

The total number of bacteria determined by AODCM remained relatively constant throughout the experimental period for all treatments, except for bacteria maintained in broth: the number of bacteria in

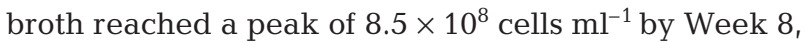
and the numbers started to decline slightly thereafter. These cells gradually became more difficult to stain with acridine orange, making cell counts difficult. Thus, no further samples were counted using AODCM after Week 19.

The total number of bacteria present in the stream water remained constant for the first $16 \mathrm{wk}$ of the experiment and declined thereafter. The number of culturable cells present in stream water also showed a steady decline, and by Week 19 very few bacterial colonies (and in some cases no colonies at all) were obtained on Cytophaga agar and thus sampling with this medium was discontinued and the trial ended. (However, when bacteria in these samples were placed directly into broth after 9 mo, growth of the bacterium could still be observed.)

The viability of the bacteria under the different conditions was assessed for the first $10 \mathrm{wk}$ using the live/dead kit: at the end of this period, $51.6 \%$ of the bacteria maintained in broth appeared 'dead', while $94.5 \%$ of the bacteria in stream water were still viable. After this time, however, the non-viable (dead) bacteria were no longer clearly visible and thus no further samples were taken after Week 10.

\section{Scanning electron microscopy}

Bacteria from the stock cultures ( $3 \mathrm{~d}$ old) appeared as long slim rods, 5 to $8 \mu \mathrm{m}$ in length (Fig. 1a), with a few reaching 10 to $12 \mu \mathrm{m}$ in length.

Bacteria kept in broth for 1 mo (Fig. 1b) still appeared as long slim rods, 8 to $12 \mu \mathrm{m}$ in length. How- 
ever, some were enlarged either at the end or along the length of cell (Fig. 1b: grey arrows); many cells also appeared to have developed a ring-type structure (Fig. 1b: white arrows).

Bacterial cells kept in distilled water for $1 \mathrm{mo}$ (Fig. 1c) were generally shorter than bacteria kept in broth and about the same size as bacteria taken from the stock culture (Fig. 1a), although some longer rods were also observed. They generally appeared as straight rods, although some had some enlarged segments (Fig. 1c: grey arrow), or had developed ring formations (Fig. 1c: white arrow). These were less frequently observed than in bacteria maintained in broth. The bacteria appeared to retain their general morphology even after $16 \mathrm{wk}$ in distilled water. Bacteria treated with disinfectant (Fig. 1d) appeared similar to the bacteria kept in distilled water when examined 1 mo after treatment.

After keeping bacteria in stream water for $1 \mathrm{mo}$, cells appeared shorter than in bacteria subjected to the other 3 treatments (Fig. 1e). They were generally straight, but a few curved cells were also observed (Fig. 1e, white arrow). The enlarged sections seen in bacteria maintained in distilled water in Fig. 1c, were also observed in many cells treated with stream water (Fig. 1e, grey arrows). Enlarged sections within the bacterial cells are shown at greater magnification in Fig. 1f.

Bacteria kept in broth for $16 \mathrm{wk}$ were generally visible as long or ring cells with an irregular surface; a lot of cell debris was also observed (Fig. 1g). Bacteria of the same age maintained in stream water also appeared either as small rods, approximately 1 to $2 \mu \mathrm{m}$ long, or as small rings or spheres (Fig. 1h).

\section{Transmission electron microscopy}

Regardless of the conditions under which they were maintained, 4 wk after setting up the experiment, all bacteria had the same general morphology as bacteria taken from the stock culture (3 d old culture, Fig. 2a). A well-defined glycocalyx could be seen around the cells (Fig. 2a,c: grey arrows). Bacteria maintained in stream water, distilled water or treated with disinfectant retained this morphology even after 16 wk (e.g. stream water, Fig. 2b). Bacteria maintained in broth for the same period of time, however, appeared irregular in shape with deep indentations on the surface of the cell (white arrows, Fig. 2c,d). Many cells appeared

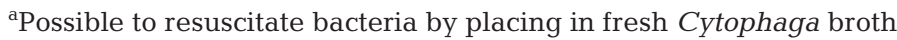

${ }^{b}$ Bacteria placed in Cytophaga broth but no growth was observed 

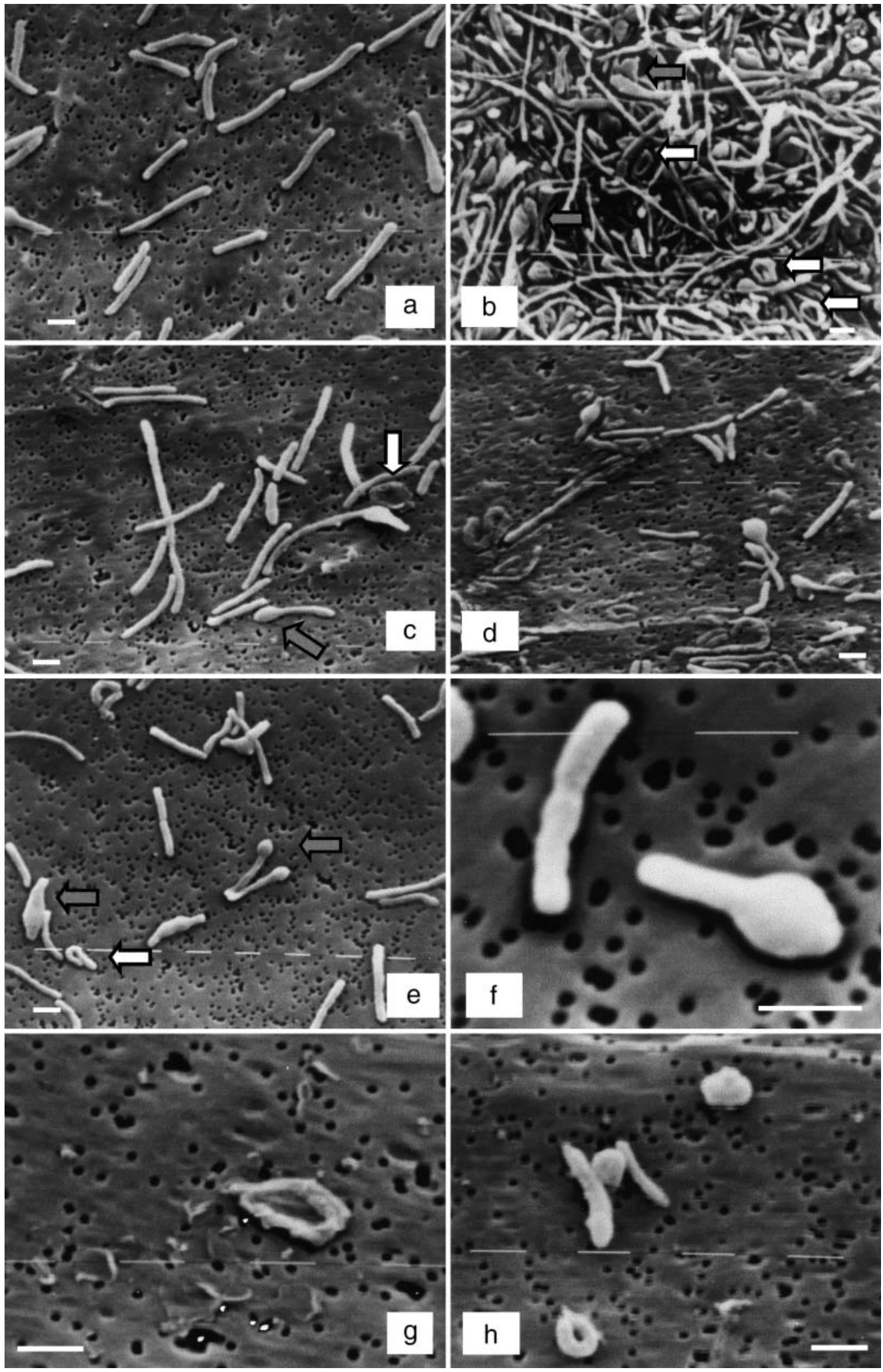

Fig. 1. Flavobacterium psychrophilum. Scanning electron microscopy of bacterium maintained in (a) Cytophaga broth for 3 d, (b) broth for approximately $4 \mathrm{wk}$, (c) distilled water for $4 \mathrm{wk}$, (d) broth after disinfection for $4 \mathrm{wk}$, (e) stream water for 4 wk, (f) stream water for $4 \mathrm{wk}$ (at a higher magnification), (g) broth for $16 \mathrm{wk}$, (h) stream water for 16 wk. Grey and white arrows in (b), (c) and (e): enlarged cell sections and ring-type stuctures, respectively; All scale bars = $1 \mu \mathrm{m}$ 

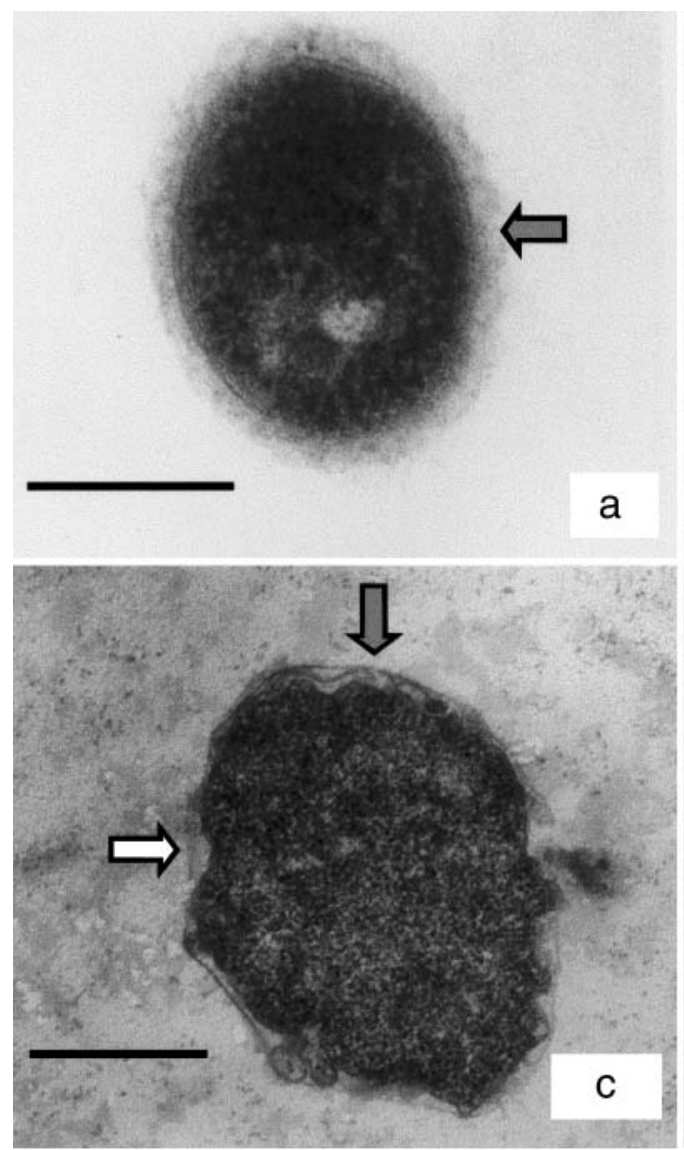

b
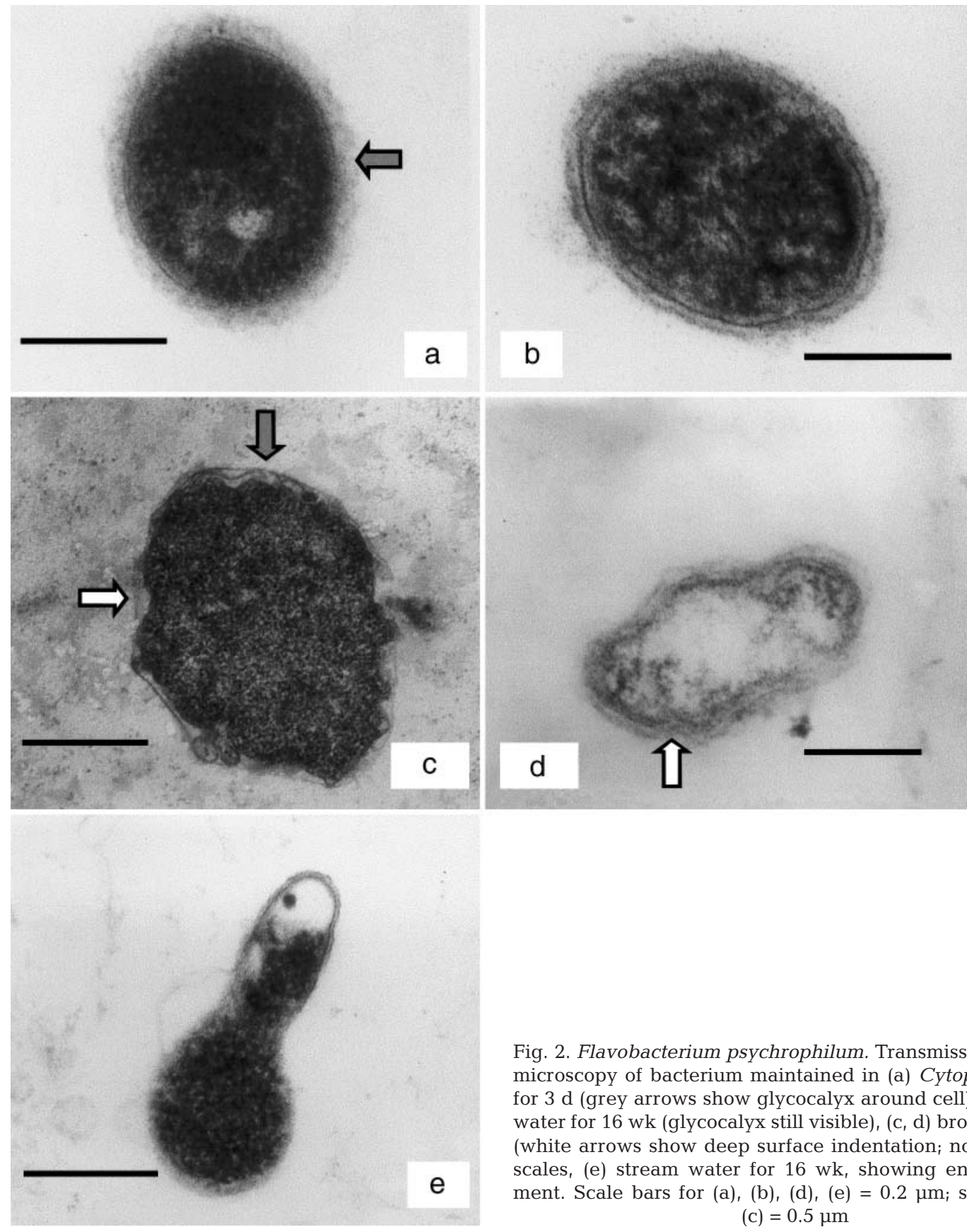

d

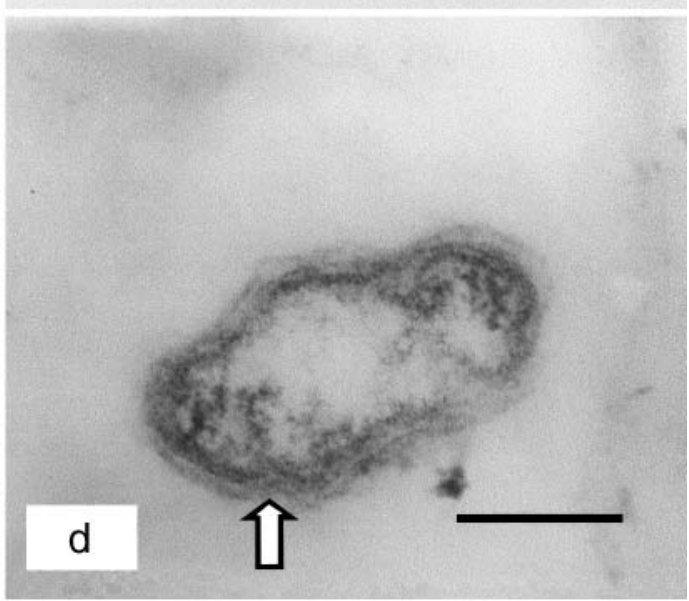

'empty', and contained large vacuoles (Fig. 2d). An example of an enlarged segment within bacteria maintained in stream water is shown in Fig. 2e.

\section{SDS-PAGE and Western blot analyses}

The SDS-PAGE (Fig. 3) and Western blot (Fig. 4) profiles of bacteria kept under the different conditions for 8 wk showed differences between the various treat-

Fig. 2. Flavobacterium psychrophilum. Transmission electron microscopy of bacterium maintained in (a) Cytophaga broth for $3 \mathrm{~d}$ (grey arrows show glycocalyx around cell), (b) stream water for 16 wk (glycocalyx still visible), (c, d) broth for $16 \mathrm{wk}$ (white arrows show deep surface indentation; note different scales, (e) stream water for $16 \mathrm{wk}$, showing enlarged segment. Scale bars for (a), (b), (d), (e) $=0.2 \mu \mathrm{m}$; scale bar for (c) $=0.5 \mu \mathrm{m}$

ments, especially for bacteria maintained in stream water. Less material was evident around the 20 to $40 \mathrm{kD}$ region with this treatment, both with silver stain (Fig. 3, Lane 4) and in the antigenic profile of Western blot analysis (Fig. 4, Lane 4). When bacteria maintained in stream water were transferred to Cytophaga broth and cultured for $3 \mathrm{~d}$, profiles were similar to those for bacteria taken direct from the stock culture, and grown for only $3 \mathrm{~d}$ (Fig. 4: Lanes 1 and 6, respectively). A band at approximately $45 \mathrm{kD}$ disappeared 


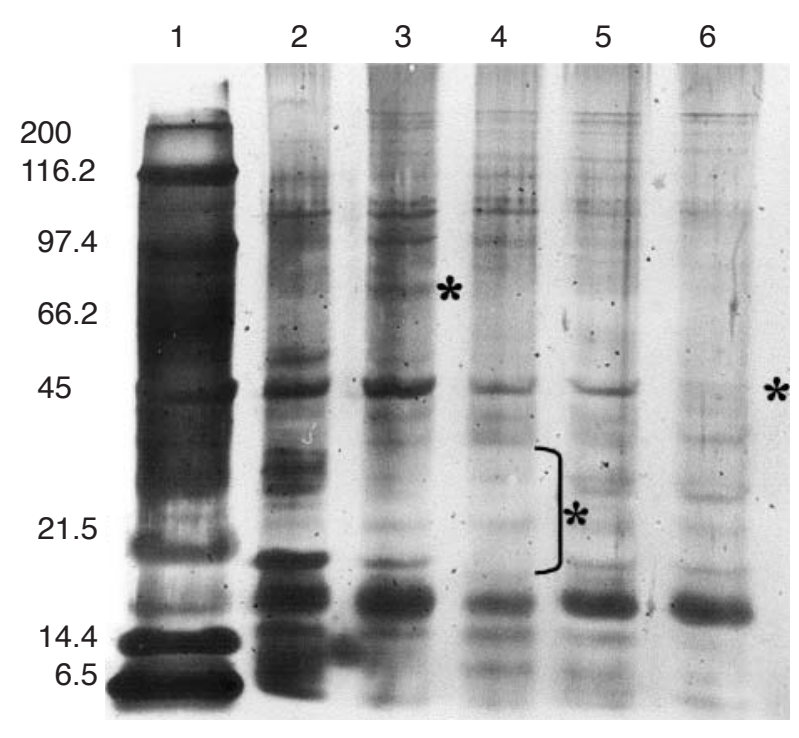

Fig. 3. Flavobacterium psychrophilum. Silver stain with $12 \%$ SDS-PAGE of bacterium maintained under different experimental conditions. Lane 1: marker, 2: stock culture, 3: bacteria in Cytophaga broth for 8 wk, 4 : in stream water for 8 wk, 5 : in distilled water for $8 \mathrm{wk}, 6$ : disinfected and then in broth for 8 wk. *: band missing

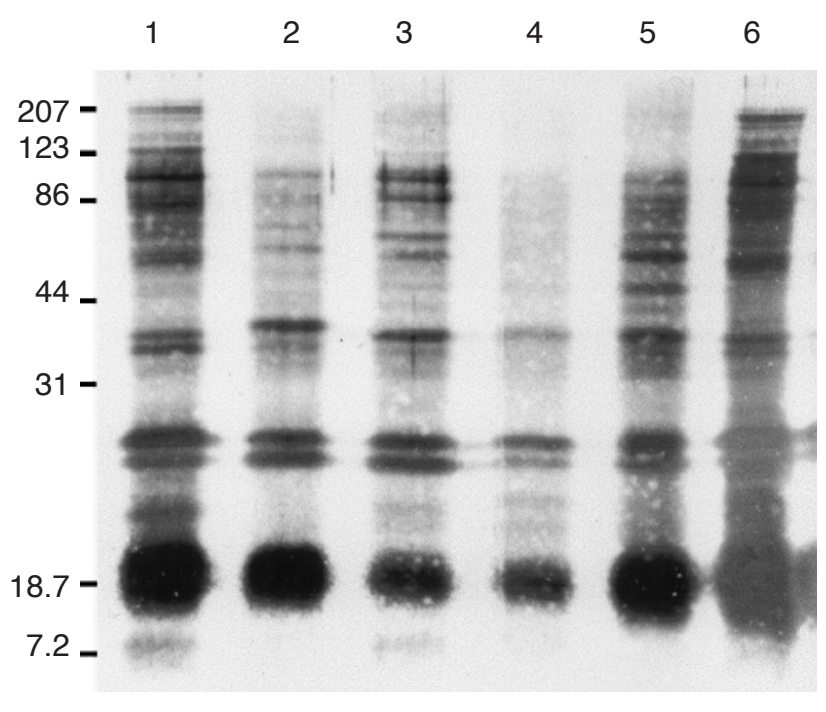

Fig. 4. Flavobacterium psychrophilum. Western blot analysis of bacterium maintained under experimental conditions using rabbit anti- F. psychrophilum B97026 serum. Lane 1: bacteria in stream water for $8 \mathrm{wk}$ and transferred to fresh Cytophaga broth for $3 \mathrm{~d}, 2$ : disinfected and then in broth for $8 \mathrm{wk}, 3$ : in distilled water for $8 \mathrm{wk}, 4$ : in stream water for $8 \mathrm{wk}, 5$ : in broth for $8 \mathrm{wk}, 6$ : stock culture

from the silver stain profile of bacteria after treatment with disinfectant (Fig. 3: Lane 6). In addition, a band of approximately $75 \mathrm{kD}$, which was evident in bacteria maintained in broth and in bacteria from fresh culture (stock culture) (Fig. 3: Lanes 3 and 2, respectively), appeared less visible in bacteria maintained in stream water, distilled water or treated with disinfectant.

\section{PCR analysis}

PCR products are represented by a band at $1078 \mathrm{bp}$. Using AODCM to count the bacteria, the sensitivity of the nested PCR method detected as few as 100 bacterial cells $\mathrm{ml}^{-1}$ (Fig. 5, Lane 15), since the technique can detect both live and dead bacteria. When only the second pair of primers (PSY1/PSY2) was used, the ability to detect bacterial cells decreased to $10^{5}$ cells $\mathrm{ml}^{-1}$ (Fig 5, Lane 5).

There appeared to be a substantial decrease in the sensitivity of the PCR with DNA extracted from the different bacterial treatments $14 \mathrm{wk}$ from the onset of the study (Fig. 6). When the single-round PCR was used, the sensitivity of the reaction, shown in Fig. 6a, was much lower than that shown in Fig. 5, where $10^{5}$ bacterial cells $\mathrm{ml}^{-1}$ or more could be detected.

When a nested PCR (2-round PCR) was performed on DNA extracted from bacteria 14 wk from the onset of the study, there appeared to be a difference in the intensity of the bands obtained with bacteria taken from the 4 different treatments (Fig. 6b), even though the same number of the bacteria were used in this assay $\left(2 \times 10^{7}\right.$ bacteria $\left.\mathrm{ml}^{-1}\right)$ to that presented in Fig. 5 . The intensity of the band was stronger with bacteria maintained in broth and stream water than with bacteria maintained in distilled water or treated with disinfectant. A region of smearing, close to the expected band of $1078 \mathrm{bp}$, was also evident for bacteria maintained in broth and stream water (Fig. 6b: Lanes 1 and $4)$.

\section{DISCUSSION}

All microbes encounter some level of starvation at some point in their life cycle. There appear to be only a few exceptions to this rule, e.g. bacteria living in the intestine of their host or grown artificially in an enriched medium (Morita 1985). The ability of Flavobacterium psychrophilum to survive under conditions of starvation in different media for a period of $19 \mathrm{wk}$ was investigated herein. Morphological changes, together with changes in their viability and culturability, were examined. In addition, the ability to detect starved cells by PCR was also evaluated.

Different bacterial species vary in their ability to survive under adverse environmental conditions. Some can survive for only a few hours, others can survive for many years. Many different factors are involved in the 


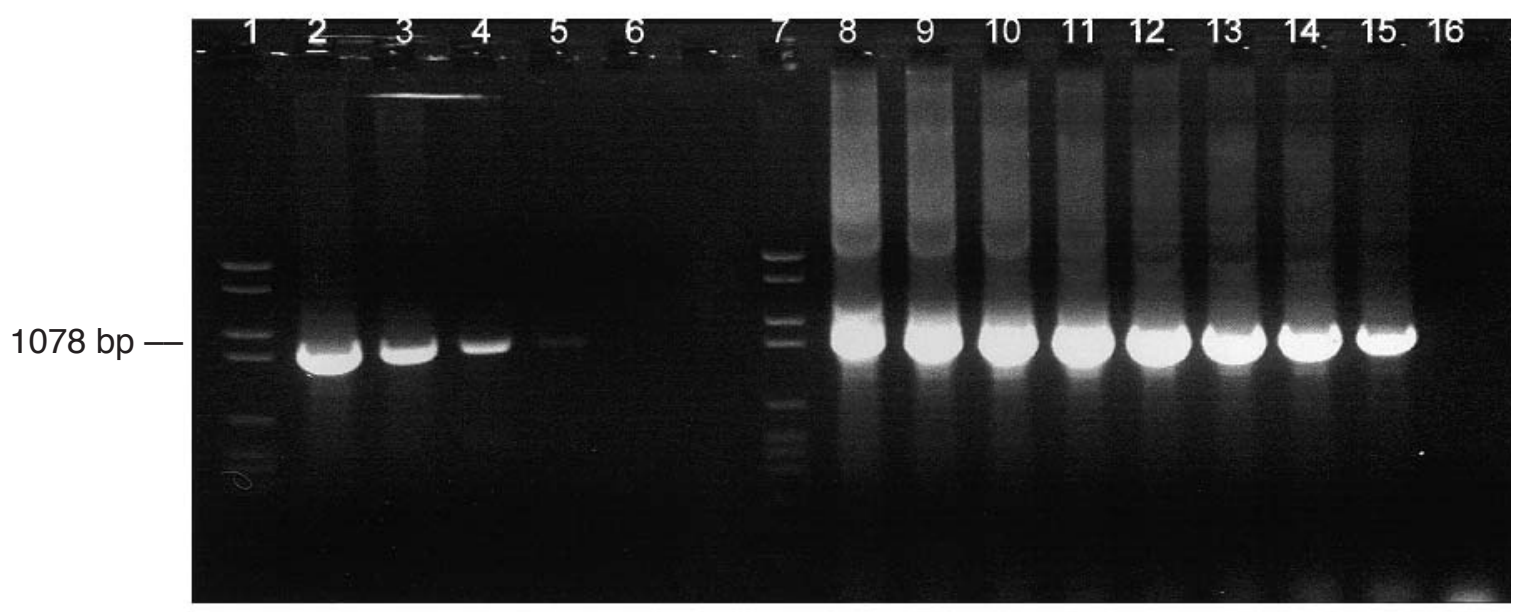

Fig. 5. Flavobacterium psychrophilum. Sensitivity of polymerase chain reaction (PCR) for bacterium cultured for $3 \mathrm{~d}$ in Cytophaga broth (1\% agarose gel). Lanes 1, 7: marker; Lanes 2 to 6: F. psychrophilum suspensions $\left(10^{8}\right.$ to $10^{4}$ cells ml $\left.{ }^{-1}\right)$ using only Primers PSY1 and PSY2; Lanes 8 to 16: F. psychrophilum suspensions $\left(10^{8}\right.$ to $10^{1}$ cells $\left.^{-1}\right)$ using both pairs of primers

survival of microbes under starvation, and because of the complex interactions between bacteria and their environment it is difficult to mimic states of starvation under laboratory conditions (Dawes 1985). Internal influences also affect the ability of the cells to survive under different environmental conditions, such as the endogenous metabolism of the bacterium, the presence of material stored within the bacterial cell, the energy requirement of the cell, adenylate energy charge and the preservation of membrane potential. However, since no bacterial species exists solely in one particular environment, it has to be able to cope with a variety of external conditions to be able to survive. Competition, predation, light, temperature and $\mathrm{pH}$ fluctuations all have a significant influence on the ability of a bacterium to survive in its environment (Panicker et al. 1994).

It is well established that Flavobacterium psychrophilum is a fastidious organism and that many problems exist with its detection using antibodybased techniques (Lorenzen \& Karas 1992, Lorenzen \& Olesen 1997, Faruk et al. 2002) or culture methods (Daskalov et al. 1999, Michel et al. 1999). The kit used in the present study to test the viability of F. psychrophilum has been previously used to evaluate the viability and especially the permeability of starved microbes. Joux et al (1997) for example, used the kit in flow cytometry to test the membrane permeability of starved Salmonella typhimurium. Michel et al. (1999) reported differences in the viability of cells measured with the kit compared to levels measured from colony counts and fluorescent staining methods. In the present study, the viability of $F$. psychrophilum obtained with the kit and by culture was examined weekly over a 10 wk period. However, slight modifications were introduced to the kit protocol for optimal use; 1 component, propidium iodide, was replaced

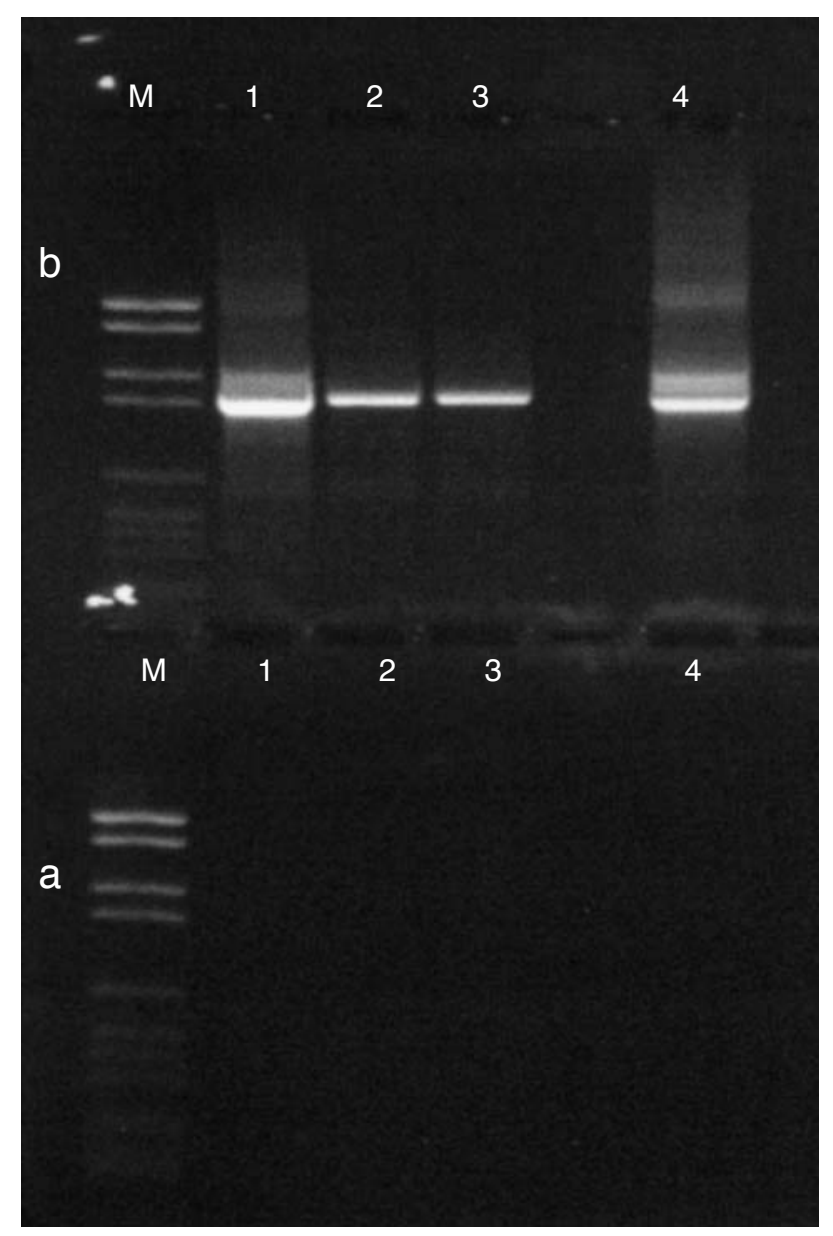

Fig. 6. Flavobacterium psychrophilum. A $1 \%$ agarose gel of polymerase chain reaction (PCR) products of DNA extracted from bacteria kept for 14 wk under different experimental conditions (a) 1-round PCR with Primers PSY1/PSY2; (b) nested PCR with primers 2OF/1500R and PSY1/PSY2. Lane M: marker; 1: bacteria in Cytophaga broth; 2: bacteria in distilled water; 3 : bacteria treated with disinfectant; 4 : bacteria in stream water 
with ethidium homodimer-1, a large molecule almost double the size of propidium iodide. Preliminary analysis with propidium iodide showed that when 3 to $4 \mathrm{~d}$ old cultures of F. psychrophilum cells were subjected to any form of pressure, such as centrifugation, filtration, or placement between microscope slides and coverslips, all cells appeared red, indicating that all bacteria were 'dead'. Substituting propidium iodide with ethidium homodimer-1 rectified this. Ethidium homodimer-1 works in the same way as propidium iodide; however it is twice the size of propidium iodide, and is thus less able to enter cells where the cell membrane integrate is only slightly compromised.

The results of the study show that growth of the bacterium on Cytophaga agar did not correspond to the viability of the bacterium obtained with the live/dead kit and that more bacteria appeared viable than culturable. This difference was greater than that seen by Michel et al. (1999), possibly due to the situation in the present study whereby the bacteria entered a viable but non-culturable state under starvation. The ability of the microbes to enter a viable but non-culturable state is known for many species. This is an important consideration for accurate determination of cell numbers or detection of the bacterium in different environmental samples by plate culture, if plate culture is the only method used to quantify or identify the bacterium (Huq \& Colwell 1994).

Starved cells exhibit an enhanced resistance to heat and to oxidative and osmotic shock (Barcina et al. 1997); in some cases increased surface hydrophobicity occurs, as in Photobacterium damselae ssp. piscicida (Magarinos et al. 1994). The metabolic activity of the cells is reduced and the cells stop multiplying (Magarinos et al. 1994). This was also the case with Flavobacterium psychrophilum, since the total number of bacteria maintained in stream water remained the same throughout the duration of the experiment. The viability of bacteria maintained in stream water assessed with the kit was substantially higher than of bacteria maintained in broth. Perhaps a lower metabolic activity of the cells maintained in stream water delayed the death of the cells due to the limited nutrients in the water. The opposite was true for bacteria maintained in broth, possibly due to a build-up of toxic by-products as a result of the bacteria metabolising the nutrients in the broth. Thus, the number of bacteria present in the broth may have affected the survival rate of the bacteria. Using a lower number of bacteria at the start of the experiment may have minimised this effect.

One problem experienced with the kit was an overestimation of live cells as time progressed, with dead cells becoming less visible after the first $10 \mathrm{wk}_{\text {; }}$ hence the kit was only used for the first 10 wk of the study.
Despite this, the method can provide a rapid and easy alternative to flow cytometry for determining cell numbers.

Although CFUs were not determined after Week 19 following the setting up of the study, it was still possible to resuscitate bacteria maintained in stream water by transferring them to Cytophaga broth, even after 9 mo. This phenomenon has also been observed for Micrococcus luteus by Kell et al. (1994), who found starved bacteria were incapable of growing when placed on agar plates, but recovered after transfer to a weak nutrient broth.

Although the bacterium can survive in stream water for more than $4 \mathrm{mo}$, its survival in distilled water is very short. No viable bacteria could be detected by either culture counts or the live/dead kit $1 \mathrm{~h}$ after being placed in distilled water. Michel et al. (1999) found Flavobacterium psychrophilum to be highly susceptible to osmotic changes.

Changes in the cell morphology of Flavobacterium psychrophilum have been noted with increased culture time (Kondo et al. 2001). Alterations in the cell morphology during starvation are also of interest. Some bacterial species form specific structures, such as spores (e.g. Bacillus cereus), while others assume a vegetative state, enabling them to survive under adverse conditions. F. psychrophilum maintained in stream water adopts the latter state. During starvation in stream water the bacterium tends to shrink and become round. The formation of dwarf cells is a common feature of many bacterial species to help them survive long periods of starvation. For example, Vibrio parahaemolyticus has been observed to change from rods to spheres under starvation (Jiang \& Chai 1996); F. psychrophilum maintained in broth on the other hand, tend to form long slender filamentous cells. When maintained in broth or stream water for long periods of time, the cells appear to develop areas of swelling across the cell. The function of these swellings is unknown, since F. psychrophilum is a nonspore forming species. They may possibly be an intermediate stage in the development of dwarf cells. Cells of F. psychrophilum also tend to curl and even develop ring forms, especially when maintained in broth. Similar types of formation have been reported by Ostland et al. (1994) for F. branchiophilum. Little information is available as to the cause of this change in morphology. Interestingly, the bacterium was able to retain the glycocalyx around its cell regardless of the environmental conditions in which it is maintained, although slight differences were apparent in the thickness of this layer between the different treatments.

Some species of bacteria have been reported to produce either less or different substances during starvation. For example, metabolic and structural changes 
have been observed in some strains of Escherichia coli under starvation, with the loss of cytoplasmic proteins and an increase or decrease in some enzyme levels (Papapetropoulou et al. 1993). Rahman et al. (1998), on the other hand, found that starved Aeromonas hydrophila produced different outer membrane proteins. In the present study, there was little difference between the silver-stained SDS-PAGE profiles of bacteria maintained under the different treatments. This was also true for their corresponding Western blot profiles analysed with rabbit antiFlavobacterium psychrophilum serum, although the bacteria maintained in stream water for $8 \mathrm{wk}$ appeared to have less lower molecular weight material (20 to $40 \mathrm{kD}$ ) than bacteria maintained in broth or bacteria taken from the stock culture (a 3 d old culture). Faruk (2000) identified glycoproteins and carbohydrates in this region of the bacterium's SDS-PAGE profile. Roslev \& King (1995) reported a similar loss of low molecular weight material from starved methanotrophic bacteria, suggesting that this was due to either the low metabolism of cells or to a substantial reduction in their size. When F. psychrophilum maintained in stream water were transferred to fresh Cytophaga broth, they regained both their original morphology and the SDS-PAGE and Western blot profiles exhibited by fresh cultures. Changes in the SDS-PAGE and Western blot profiles may reflect changes in the virulence or pathogenicity of the bacterium during starvation, although further work is need to confirm this.

Finally, a decrease in the sensitivity of the PCR and an area of smearing around the expected region for the PCR products were observed, indicating a possible deterioration of the bacterial DNA, as suggested by Morgan et al. (1991) in the case of starved Aeromonas salmonicida. The decrease seen in the fluorescence signal of the live/dead kit may also be as a result of this deterioration. Environmental factors, such as water temperature or the existence of other microbes that are able to destroy and consume dead cells, can also affect the persistence of DNA within the cells, as observed by Dupray et al. (1997) and Joux et al. (1997).

To date, our knowledge of the survival of Flavobacterium psychrophilum outside the host fish is limited. This study investigated changes that occur in starved F. psychrophilum under different conditions of starvation, and although a number of changes were highlighted in the bacterium during starvation, clearly the effects of starvation on the pathogens virulence and pathogenesis need to be investigated, including the surface hydrophobicity of the bacterium and its ability to attach to eggs or host cells (Vatsos et al. 2001). Virulence mechanisms and resistance to various antimicrobial agents may also be altered during starvation.
Acknowledgements. We would like to thank Mr. Linton Brown for his help with the processing of samples for electron microscopy. This study was financially supported by State Scholarships Foundation (SSF) of Greece.

\section{LITERATURE CITED}

Anacker RL, Ordal EJ (1959) Studies on the myxobacterium Chondrococcus columnaris I. Serological typing. J Bacteriol 78:25-32

Barcina I, Lebaron P, Vives-Rego J (1997) Survival of allochthonous bacteria in aquatic systems: a biological approach. FEMS Microbiol Ecol 23:1-9

Bernardet JF (1989) 'Flexibacter columnaris': first description in France and comparison with bacterial strains from other origins. Dis Aquat Org 6:37-44

Borg AF (1960) Studies on myxobacteria associated with disease in salmonid fishes. J Wildl Dis 8:1-85

Brown L, Cox W, Levine R (1997) Evidence that the causal agent of bacterial cold-water disease Flavobacterium psychrophilum is transmitted within salmonid eggs. Dis Aquat Org 29:213-218

Daskalov H, Austin DA, Austin B (1999) An improved growth medium for Flavobacterium pshychrophilum. Lett Appl Microbiol 28:297-299

Dawes E (1985) Starvation, survival and energy reserves. In: Fletcher M, Floodgate G (eds) Bacteria in their natural environments. Academic Press, London, p 43-81

Decostere A, Lammens M, Haesebrouck F (2000) Difficulties in experimental infection studies with Flavobacterium psychrophilum in rainbow trout (Oncorhynchus mykiss) using immersion, oral and anal challenges. Res Vet Sci 69: 165-169

Dupray E, Caprais M, Derrien A, Fach P (1997) Salmonella DNA persistence in natural seawaters using PCR analysis. J Appl Microbiol 82:507-510

Faruk RA (2000) Characterisation of Flavobacterium psychrophilum, the causative agent of rainbow trout fry syndrome. PhD thesis, University of Stirling, Stirling

Faruk RA, Campbell RE, Thompson KD, Rangdale RE, Richards RH (2002) The potential use of an enzyme-linked immunosorbent assay (ELISA) to distinguish between Flavobacterium psychrophilum isolates. Bull Eur Assoc Fish Pathol 22:354-365

Hobbie J, Daley R, Jasper S (1977) Use of Nuclepore filters for counting bacteria by fluorescence microscopy. Appl Environ Microbiol 33:1225-1228

Holt R (1987) Cytophaga psychrophila, the causative agent of bacterial coldwater disease in salmonid fish. PhD thesis, Oregon State University, Corvallis, OR

Huq A, Colwell R (1994) Vibrios in the marine and estuarine environments. J Mar Biotechnol 3:60-63

Iida Y, Mizokami A (1996) Outbreaks of coldwater disease in wild ayu and pale chub. Fish Pathol 31:157-164

Izumi S, Wakabayashi H (1997) Use of PCR to detect Cytophaga psychrophila from apparently healthy juvenile ayu and coho salmon eggs. Fish Pathol 32:169-173

Jiang X, Chai TJ (1996) Survival of Vibrio parahaemolyticus at low temperatures under starvation conditions and subsequent resuscitation of viable, nonculturable cells. Appl Environ Microbiol 62:1300-1305

Joux F, Lebaron P, Troussier M (1997) Succession of cellular states in a Salmonella typhimurium population during starvation in artificial seawater microcosms. FEMS Microbiol Ecol 22:65-76

Kell DB, Davey HM, Mukamolova GV, Votyakova TV, 
Kaprelyants AS (1994) A summary of recent work on dormancy in nonsporulating bacteria: its significance for marine microbiology and biotechnology. Third International Marine Biotechnology Conference (IMBC ‘94) held in Tromso, Norway 7-12 August 1994. J Mar Biotechnol 3: $24-25$

Kondo M, Kawai K, Yagyu K, Nakayama K, Kurohara K, Oshima S (2001) Changes in the cell structure of Flavobacterium psychrophilum with length of culture. Microbiol Immunol 45:813-818

Kondo M, Kawai K, Kurohara K, Oshima S (2002) Adherence of Flavobacterium psychrophilum on the body surface of the ayu Plecoglossus altivelis. Microbes Infect 4:279-283

Kumagai A, Yamaoka S, Takahashi K, Fukuda H, Wakabayashi H (2000) Waterborne transmission of Flavobacterium psychrophilum in coho salmon eggs. Fish Pathol $35: 25-28$

Laemmli UK (1970) Cleavage of structural proteins during assembly of the head of bacteriophage T4. Nature 227 : 680-685

Lorenzen E, Karas N (1992) Detection of Flexibacter psychrophilus by immunofluorescence in fish suffering from fry mortality syndrome: a rapid diagnostic method. Dis Aquat Org 13:231-234

Lorenzen E, Olesen NJ (1997) Characterization of isolates of Flavobacterium psychrophilum associated with coldwater disease or rainbow trout fry syndrome. Dis Aquat Org 31: 209-220

Lorenzen E, Dalsgaard I, From Hansen EM, Hørlyck V, Korsholm H, Mellergaard S, Olesen NJ (1991) Preliminary investigations of fry mortality syndrome in rainbow trout. Bull Eur Assoc Fish Pathol 11:77-79

Madetoja J, Nyman P, Wiklund T (2000) Flavobacterium psychrophilum, invasion into and shedding by rainbow trout Oncorhynchus mykiss. Dis Aquat Org 43:27-38

Madsen L, Dalsgaard I (1999) Reproducible methods for experimental infection with Flavobacterium psychrophilum in rainbow trout Oncorhynchus mykiss. Dis Aquat Org 36:169-176

Magarinos B, Romalde J, Barja J, Toranzo A (1994) Evidence of a dormant but infective state of the fish pathogen Pasteurella piscicida in seawater and sediment. Appl Environ Microbiol 60:180-186

Michel C, Antonio D, Hedrick R (1999) Production of viable cultures of Flavobacterium psychrophilum: approach and control. Res Microbiol 150:351-358

Morgan J, Cranwell P, Pickup R (1991) Survival of Aeromonas salmonicida in lake water. Appl Environ Microbiol 57: $1777-1782$

Editorial responsibility: David Bruno,

Aberdeen, UK
Morita R (1985) Starvation and miniaturisation of heterotrophs, with special emphasis on maintenance of the starved viable state. In: Fletcher M, Floodgate G (eds) Bacteria in their natural environments. Academic Press, London, p 111-130

Nation JL (1983) A new method using hexamethyldisilazane for preparation of soft insect tissue for scanning electron microscopy. Stain Technol 58:347-351

Ostland V, Lumsden J, MacPhee D, Ferguson H (1994) Characteristics of Flavobacterium branchiophilum, the cause of salmonid bacterial gill disease in Ontario. J Aquat Anim Health 6:13-26

Panicker S, Sheena RT, Ravindran PC (1994) Survival ability of Gram negative enteric bacteria in aquatic environments of central Kerala. J Zool Soc India 4:70-72

Papapetropoulou M, Zoumbou K, Nicolopoulou A (1993) Metabolic and structural changes in E. coli cells starved in seawater: biogeochemical cycles of specific pollutants (activity K), survival of pathogens. Final report of research project (1992-1993). Athens (Greece). Medit Action Plan Tech Rep Ser 76:39-56

Rahman MH, Suzuki S, Kusuda R, Kawai K (1998) Changes in the outer membrane and S-layer protein profiles of Aeromonas hydrophila by starvation. Fish Pathol 33: 275-279

Roslev P, King G (1995) Aerobic and anaerobic starvation metabolism in methanotrophic bacteria. Appl Environ Microbiol 61:1563-1570

Thorsen BK, Enger Ø, Norland S, Hoff KA (1992) Long-term starvation survival of Yersinia ruckeri at different salinities studied by microscopical and flow cytometric methods. Appl Environ Microbiol 58:1624-1628

Toyama T, Kita-Tsukamoto K, Wakabayashi H (1994) Identification of Cytophaga psychrophila by PCR targeted 16S ribosomal RNA. Fish Pathol 29:271-275

Wiens GD, Turaga PSD, Kaatari SL (1990) Western blot analysis of fish pathogens. In: Stolen JS, Fletcher TC, Anderson DP, Robertson BS, van Muiswinkel WB (eds) Techniques in fish immunology. SOS Publications, Fair Haven, CT p $87-94$

Wiklund T, Kaas K, Lönnstrom L, Dalsgaard I (1994) Isolation of Cytophaga phychrophila (Flexibacter psychrophilus) from wild and farmed rainbow trout (Oncorhynchus mykiss) in Finland. Bull Eur Assoc Fish Pathol 14:44-46

Vatsos IN, Thompson KD, Adams A (2001) Adhesion of the fish pathogen Flavobacterium psychrophilum to unfertilized eggs of rainbow trout (Oncorhynchus mykiss) and nhexadecane. Lett Appl Microbiol 33:178-182

Submitted: October 3, 2002; Accepted: March 20, 2003

Proofs received from author(s): August 21, 2003 